\title{
The spatial dynamics of niche trajectory: The case of wave energy
}

\author{
Margarida Fontes $^{\mathrm{a}, \mathrm{b}, *}$, Cristina Sousa $^{\mathrm{b}}$, João Ferreira ${ }^{\mathrm{a}}$ \\ a LNEG-National Laboratory for Energy and Geology, Campus do Lumiar, Estrada do Paç do Lumiar, 1649-038 Lisboa, Portugal \\ b DINÂMIA'CET-IUL, ISCTE-University Institute of Lisbon, Avenida das Forças Armadas, Edificio ISCTE, 1649-026 Lisboa, Portugal
}

\section{A R T I C L E I N F O}

\section{Article history:}

Received 17 October 2014

Received in revised form

18 September 2015

Accepted 19 September 2015

Available online $\mathrm{xxx}$

\section{Keywords:}

Niche dynamics

Space

Wave energy technology

Strategic niche management

Socio-cognitive perspective

Portugal

\begin{abstract}
A B S T R A C T
This paper proposes that niches, as protected spaces where technologies are developed and articulated with societal needs, transcend territorial boundaries, encompassing communities and actions that span several spatial levels. To support this assertion, the paper builds on the socio-cognitive perspective to niche development and extends it, introducing a new dimension - space - thus broadening and "spatializing" the concept of technological niche. This framework is applied to the case of wave energy. Empirical research combines a generic analysis of the construction of an "overall niche space" with a detailed analysis of the processes taking place in Portugal, which was one of the pioneers in the emerging field. The results confirm the niche multi-spatial dynamics, showing that it is shaped by the interplay between a niche relational space constructed by actors' actions and interactions, and the territorial effects introduced by their embeddedness in particular geographical and institutional settings.
\end{abstract}

(C) 2015 Elsevier B.V. All rights reserved.

\section{Introduction}

The spatial dimension has recently started to receive greater attention in socio-technical transitions research (Coenen et al., 2012; Raven et al., 2012). But despite the advances at this level (Hansen and Coenen, in print), the literature on niche formation and development still frequently associates the niche to (narrow) territorial boundaries and localised networks. However, this is not necessarily the case (Raven et al., 2012): some technological niches effectively transcend these boundaries, encompassing communities and actions that span several spatial levels, a type of behaviour still imprecisely captured by the niche literature. In this paper we develop a conceptual framework that intends to provide a more explicit treatment of space in niche development, and apply it to the case of the wave energy technological niche.

The process of niche development and breakthrough has been addressed by the strategic niche management literature (Kemp et al., 1998; Schot and Geels, 2007; Verbong et al., 2008). Recent advances in this literature led to a conceptualisation of niche development as a non-linear trajectory along which the emerging field is structured through a socio-cognitive process (Geels and Raven, 2006; Raven and Geels, 2010). This approach has provided significant contributions to an understanding of the complex processes that occur in the niche space, by moving the focus beyond individual experiments and introducing the notion of a socially and cognitively constructed "global niche level". From a social perspective, the global niche consists of the global network that encompasses the emerging community. From a cognitive perspective the global niche consists of increasingly articulated and stable global rules and expectations (Geels and Deuten, 2006). But, although spatial issues (geographical and relational) are often implicit in the discussion of the processes that occur in local experiments and at the

\footnotetext{
* Corresponding author at: LNEG-National Laboratory for Energy and Geology, Campus do Lumiar, Estrada do Paço do Lumiar, $1649-038$ Lisboa, Portugal.

E-mail addresses: margarida.fontes@lneg.pt (M. Fontes), Cristina.Sousa@iscte.pt (C. Sousa), joaofpf@hotmail.com (J. Ferreira).
} 